\title{
A Study on Audit Information Systems Improved Model based on Public Internal Audit Paradigm Shift
}

\author{
Jong-Suk Park ${ }^{1}$, Young-Chul $\mathrm{Oh}^{2}$, Jae-Gon $\mathrm{Yoo}^{3}$, Yongtae Shin ${ }^{4}$ and Jong-Bae \\ $\operatorname{Kim}^{5^{*}}$ \\ ${ }^{1,2}$ Dept. of IT Policy and Mgmt., Graduate School of Soongsil Univ., Seoul 156- \\ 743, Korea \\ ${ }^{3,4,5 *}$ Graduate School of Software, Soongsil University, Sangdo-dong, Dongjak-gu, \\ Seoul, Korea \\ 1rayman@cgbest.co.kr, ${ }^{2}$ oyc@s3i.co.kr, ${ }^{3}$ worhs0410@gmail.com, \\ ${ }^{4}$ shin@ssu.ac.kr, ${ }^{5 *} k j b 123 @ s s u . a c . k r$
}

\begin{abstract}
In the recent work environment, any firm or organization can't guarantee the achievement of its strategic goals, that is, its success without utilizing IT well, so the IT became the object of main attention, and the reliance on the IT gets more intensified in all business fields. Therefore, each firm and public institute take enormous efforts for setting their internal audit systems appropriate for the recent business environment. Especially as the Public Audit Act began to take in effect from 2010, its raised the necessity to develop a new internal audit administration meeting a more advanced internal audit body's role and its status as well as the changes in the administration different from the past administration. Reflecting the past, the existing internal audit activities have done around the post-exposure approaching to the known risks or a kind of fragmentary checkup around samples. Besides, the existing internal audits have focused on pointing out the organization's problems and controlling them. So the organization being audited did not fully accept the internal audit results and there were also some aspects not meeting the internal customer's needs. Therefore this study aimed to propose an improved model of audit information system supporting the recent audit trends (enhancing the efficiency of work process and consulting) in order to draw out a more strategic improvement plan after analyzing the status quo of public firms' internal audits and their problems through the review of existing studies and literature about the theme.
\end{abstract}

Keywords: Internal Audit, Risk, Audit Paradigm, Audit information system, specimen

\section{Introduction}

Recent management environment undergoes rapid changes like that most trade barriers between countries are removed, the national economy's mutual correlations are increased, and the customers' expectation levels get higher and more picky due to the quick distribution of information via social network services(SNS). Counteracting to such continually changing management environment, many domestic firms' internal audit functions are changing their work focus from the past internal audit featuring the analysis on trade behaviors and the detection \& exposure of problems to the future-oriented audit contributing to the enhancement of firm's comprehensive project abilities through the improvement of work process.

$5^{\star}$ Corresponding author. Tel. : +82-10-9027-3148.

Email address: kjb123@ ssu.ac.kr(Jong-Bae Kim). 
Also the basic paradigm of administration is being conversed to the direction emphasizing outcomes, achievements or services rather than regulations and procedures around OECD members, and there are being executed various innovative actions for increasing the government's work efficiency and securing the performance responsibility like the privatization of public firms, the becoming public firms, the performance management system, the administration service charter, the accrual base accounting, and the open of appointment chance for public officials. Hence, domestic, public firm's audit functions are changing its work focus from the past internal audit featuring the analysis on trade behaviors and the detection \& exposure of problems to the future-oriented audit contributing to the enhancement of firm's comprehensive project abilities through the improvement of work process. Besides, as many foreign multi-national firms enter in Korean markets and some techniques of advanced internal audit are handed over to our firms, so many domestic firm' interest in the internal audit is more increased. And as a public firm as an economic subject that does the management activities instead of the government for accomplishing the government's policy goals and its success or failure directly leads to the reinforcement of national competitiveness and the promotion of people's welfare, so given that the public firm internal audit's importance.

It's the natural mission that it should help the government in accomplishing its management purpose by reinforcing its role and capabilities may be an important task to a stated-owned firm or its government. So a public firm's internal audit has to change its direction from the existing control system having exposed problems and criticized responsible men for the problems to the new role evaluating the management system and removing potential problems in advance, and removing unnecessary controls and procedures in the state-owned firm, so enabling the quick work flow and the efficient provision and support of administrative services. However, the existing internal audits have emphasized on their objectivity and transparency, and standardized, homogenized and objectified the audit target, the audit scope and the audit method. and checked up around external things, so it has been identified that existing internal audit had limits in dealing the organization's creativity in terms of knowledge \& IT, and had problems not meeting the internal customer's needs. They had an idea that the internal audit itself should be changed to a creative, progressive, dynamic audit and not the formal, standardized, frame work is the time that there's a need for the foundation of internal audit and institutional improvement that can increase the work efficiency through the introduction of a scientific, systematized, year-round monitoring system against the audit target's works and the quantification and evaluation of various risks in the organization, furthermore, can support and contribute the organization's vision accomplishment and performance generation through the whole-organization's risk management.

This study purposed to draw out a method to efficiently manage the audit resource on the basis of the idea that the audit resource is limited in spite of the expansion of audit scope and the increase of audit works as the common problems of internal audit bodies, and also to propose a new audit information system model appropriate for IT times where main assets are organized into intangible knowledge \& information after comparing and analyzing the status quo of public firms' international audit information system operation and the change of audit paradigm through reviewing the problems of public firms' internal audit systems and their internal control systems through relevant literature and existing studies and comparing them with the recent trends of audit operation like the risk-based internal control method being proposed as an effective control method in a public organization's internal audit. 


\section{Theoretical Discussion and Existing Researches}

\subsection{Theoretical Discussion}

2.1.1 Definition of Internal Audit (Self-Inspection): The internal audit is an important part of organization's internal control system supervising and monitoring the management and works in the organization from an independent and objective position. Especially, as firms grows up into large ones and consequently their works become more complex, the internal audit takes the role of executive manager's eyes and ears, so it directly identifies how the executive manager's plans and orders are performed, and includes the function that when the performance results are broken away from the firm's goals, the internal audit points out the problem and suggests a solution for it [1]. According to the IIA (The Institute of Internal Auditors), the internal audit is an " independent, objective assurance and consulting activity designed for improving an organization's operation and adding its values." IIA states that such an activity helps an organization to accomplish its goal by applying some systematic approaches so that the organization can improve and evaluate the effectiveness of its risk management, control and governance process [2]. And according to the 'Public Audit Act', the " self-inspection" means the activity that the chief of audit organization body in a national administrative institute, a local government and a public institute research, checkup, identify, analyze and verify all the works and activities of institutes and people which belonged to such an organization (including the belonged institutes and groups) [3].

2.1.2 Internal Control System: Internal control system implies some institutional procedures or tools being selected in order to minimize possible risks to be happened during various planning processes, their adjustment and execution processes in an organization. Therefore the internal control system can be said as a formalized institution and procedure being established in order to induce all of the organization's all activities as well as its economic activities into the direction of meeting the organization's goal [4]. The limits of existing internal control system are caused from by the internal control system's rigidity, the passive interpretation on the system's utility, and the shortage of unified viewpoint, and the performance-oriented management style. Therefore, in order to solve such weaknesses of internal control system, it first needs to change the perception about the internal control. That is, as a firm's accounting transparency is increased, the market's reliability on the firm is consequently recovered and the firm's values are also increased. Additionally, a firm needs to express the CEO's solid willingness to the internal control system externally through the actions like raising professional personnel and securing enough budgets. Second, a firm needs to invest some fund to the internal control-related infrastructure. A firm needs to develop its competence to perform voluntarily without an external auditor's help by developing its abilities to deal accounting tasks through the actions like raising accounting professional personnel and supplementing IT system needed in performing the accounting tasks. Third, as the construction of internal control system becomes some economic burden in short term to a firm, so there needs the government's policy supports through the actions like the tax deduction system for the construction cost of internal control system. Finally, as the internal control system's important weakness is attributed to the executives, so the firm's internal audit body should induce to control the organization independently in terms of the organization's format and real contents by expanding the board of directors' role and the auditor's role monitoring the firm. 


\subsection{Internal Audit's Scope and Role}

The internal audit is an important part of organization's internal control system supervising and monitoring the management and works in the organization from an independent and objective position. Especially, as firms grows up into large ones and consequently their works become more complex, the internal audit takes the role of executive manager's eyes and ears, so it directly identifies how the executive manager's plans and orders are performed, and includes the function that when the performance results are broken away from the firm's goals, the internal audit points out the problem and suggests a solution for it. According to the internal audit standards being established by IIA (The Institute of Internal Auditors), the internal audit's tasks are classified into 5 categories $[1,5]$.

[Table 1] Internal Audit's Scope

\begin{tabular}{|c|c|}
\hline Audit Classification & Audit Scope \\
\hline \multirow{3}{*}{$\begin{array}{l}\text { Compliance Audit } \\
\text { (Detective) }\end{array}$} & Audit whether the information is appropriate. \\
\hline & $\begin{array}{l}\text { Audit whether the firm complies to all relevant } \\
\text { regulations. }\end{array}$ \\
\hline & Audit about the firm's asset protection. \\
\hline $\begin{array}{l}\text { Efficiency Audit } \\
\text { (Efficiency Test) }\end{array}$ & Audit whether the firm efficiently uses its resources. \\
\hline $\begin{array}{l}\text { Effectiveness Audit } \\
\text { (Effectiveness Test) }\end{array}$ & Audit how much the firm accomplished in its goals. \\
\hline
\end{tabular}

As it is seen that such internal audit's function is in the role minimizing the all risks in order to maximize a firm's value, so it is the trend that the audit's portion is expanded from the posterior compliance audit (detective) to the prior effectiveness audit(consultant) (Yeongha, Lee, 2004). Meanwhile, according to the IIA's benchmarking data, $93 \%$ of domestic, public firms responded that the internal auditor's role was to evaluate whether a firm complies relevant laws and regulations, and $92.4 \%$ of foreign firms responded the same answer, so the viewpoint about the internal auditor's role was similar between domestic, public firms and foreign firms. However concerning the item of the risk evaluation, $63 \%$ of domestic, public firms answered the risk evaluation as internal control system's one role, but $92.4 \%$ of foreign firms replied the same answer, so this result implies that domestic, public firms' interest in the internal control system's risk diagnosis was relatively much lower than foreign firms. Concerning the item of in-house consultant for improving work operation, $80 \%$ of domestic, public firms and $86.3 \%$ of foreign firms replied the in-house consultant for improving work operation was one role of internal control system, showing that there was not a significant viewpoint difference between the domestic, public firms and foreign firms. And for the item of in-house consultant about financial works, $60 \%$ of domestic, public firms and $66.8 \%$ of foreign firms answered that the in-house consultant about financial works was one role of internal control system. Investigating the internal audit's work content, the domestic internal audit was relatively more interested in detecting, exposing the firm's misconducts, and its compliance on relevant laws and regulations than foreign firms, and given that very small audit resources were allotted to the IT audit work, so it could know that the internal audit's role focused on detecting, exposing the firm's misconducts and its compliance on relevant laws and regulation rather than the firm's whole risk management aspect like the internal control system's risk diagnosis $[1,4]$. 
Table 2. Internal Audit's Work Portion

\begin{tabular}{|l|c|c|}
\hline Audit Work & $\begin{array}{c}\text { Korean, public } \\
\text { firms }\end{array}$ & $\begin{array}{c}\text { Foreign } \\
\text { Firms }\end{array}$ \\
\hline General Work Audit & $41 \%$ & $43 \%$ \\
\hline Information \& Technology(IT) Audit & $3 \%$ & $12 \%$ \\
\hline Exposure of misconducts & $9 \%$ & $3 \%$ \\
\hline Special Project & $15 \%$ & $9 \%$ \\
\hline External Audit Support & $6 \%$ & $3 \%$ \\
\hline Administration Support for Audit Activities & $7 \%$ & $8 \%$ \\
\hline Training \& Education & $4 \%$ & $4 \%$ \\
\hline Others & $15 \%$ & $18 \%$ \\
\hline
\end{tabular}

\subsection{Internal Audit's Operation Status Quo and Problems}

As a management tool needed in increasing the corresponding firm's management effectiveness and efficiently accomplishing the institute's vision, the internal audit's purposes are to diagnose the firm's work state and its problems, to draw an improvement plan, and to review how much efficient and valid the institute's internal control system is, and to check whether such internal control is met with relevant legal requirements and the firm's policy and procedure. Also the internal audit also checks whether the firm's accounting records, its financial statements and reports are valid and check them whether they are met to the firm's accounting standards. Therefore the internal audit's independence and expertise about the audit works are the basic components of internal audit. However, according to the Audit Research Institute's 2009 survey investigating the status quo of each firm's installment of self(internal) audit body and such audit body's operation, 526 institutes responded that their self-audit body's independent audit performance was inadequate due to the installment insufficiency of excusive audit bodies. $71 \%$ of the replies, 562 institutes said that their audit bodies belonged to a general department, but only $26.2 \%$ replied that their independent audit body was installed and was being operated. Concerning the question asking whether the audit-responsible employee was independent and secures audit expertise, only $46.7 \%$ of auditresponsible employees had the carrier having worked in the firm's audit body, and even their average work period was only 1.7 a year. In the item asking whether the audit-charging employee had relevant expertise and the firm secured good audit personnel, it was grasped that audit-charging employees' average work period in an audit body was about 2 years and had undergone the professional audit education in 11 months after they were moved to the firm's audit body. So it is considered that their audit knowledge and experiences were not adequate. It was found that because such audit body's efforts to secure the voluntary internal control function and the accountability were inadequate, such audit body mainly performed the audit activities around lower departments, rather than the firm's head quarter and $94.7 \%$ of audit body's actions were the warning and the admonition. And the rate of audit report's public offering to the outside was only $34.3 \%$ and most of opened audit reports were the summarized reports. Conclusionally, current audit body is comprehensively problematic in all the aspects of independence, professionalism, efficiency, and in efforts seeking for other departments' cooperation, so the audit body is requested to improve itself comprehensively and, systematically. 


\section{Internal Audit's Paradigm Change and Recent Trend}

\subsection{Internal Audit's Paradigm Change}

As the existing internal audit's activities were mainly performed around the problem exposure approaching to usually known, existing risks or were fragmentarily checked some samples, and the existing internal audit's main focus was on pointing out and controlling misconducts and risks. The existing internal audit had somewhat negative aspects that the audit results were not adequately accepted and did not meet its internal customer's needs. That is, the existing audit showed the sample audit's limits causing from the restriction of audit resources and insufficient IT support function, and due to the nonsystematic audit plan and execution as well as the absence of analysis function, there were a lot of cases intactly following the previous-year's audit techniques. Also the existing audit was short of taking efforts in actively dealing with the audit trend's change toward the risk-based audit, the reinforcement of audit competence and, was short in efforts for strategic management partnerships like carrying out active management consulting function on the basis of its evaluation on the firm's performances or its internal control system's operation efficiency.

Table 3. Changes in the Internal Audit's Roles and Functions

\begin{tabular}{|c|c|}
\hline Classific & \\
\hline Change of Audit Role & \multirow{2}{*}{$\begin{array}{l}\triangleright \text { Change the audit's role from exposing } \\
\text { misconducts and calling the charging men to take } \\
\text { the responsibility for such misconducts to evaluating } \\
\text { the system, removing problems in advance, and } \\
\text { supporting and guiding for the efficient } \\
\text { administrative service } \\
\square \text { Audit the firm's whole risk management }\end{array}$} \\
\hline "Watchdog & \\
\hline Change $\mathrm{c}$ & \multirow{2}{*}{$\begin{array}{l}D \text { Prevent reoccurring problems by recognizing } \\
\text { its relevant institute's weakness rather than the } \\
\text { firm's past accomplishments } \\
\nabla \text { Concentrate on constructing a management } \\
\text { system to secure the charging employee's } \\
\text { responsibility and the performance improvement } \\
\triangleright \text { Expand the number of recommending cases and } \\
\text { alternatives, and expand to reflect the opinions of } \\
\text { employees/departments being audited } \\
D \text { Audit enabling to support and adjust the current } \\
\text { firm's internal control system's diagnosis function }\end{array}$} \\
\hline $\begin{array}{l}\text { " } \text { Hunting } \cdot \text { Watching } \\
\Rightarrow \text { Consulting" }\end{array}$ & \\
\hline $\begin{array}{l}\text { Change } \\
\text { Personnel }\end{array}$ & \multirow{2}{*}{$\begin{array}{l}\nabla \text { More provision of audit personnel occupying } \\
\text { expertise and increase of ability to accept the audit's } \\
\text { results. } \\
\quad \text { Increase of work professionals' consulting } \\
\text { chances }\end{array}$} \\
\hline 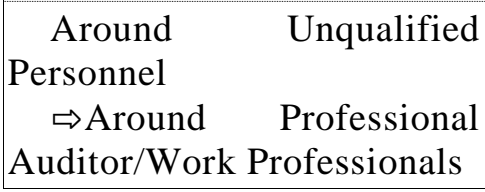 & \\
\hline
\end{tabular}




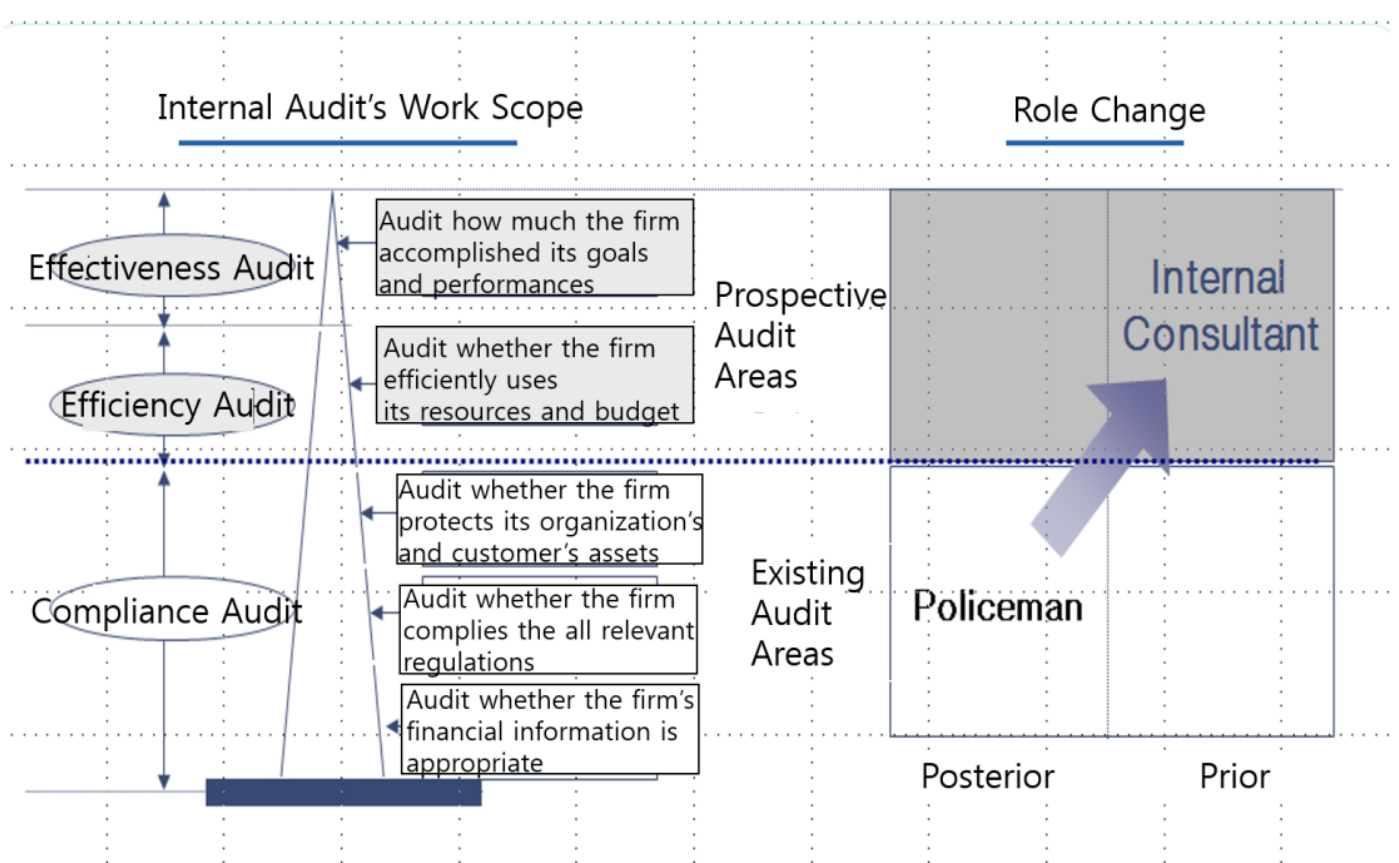

Figure 1. Changes in the Internal Audit's Role

However, as seen in the Figure 1, recent audit is changed. First, at seeing from the aspect of audit role, the recent audit emphasizes on the preliminary, preventative aspect, and its focus is changed to the aspects of work process's efficiency increase and wholefirm's risk management. Second, the recent audit is also changed from the traditional unit trade-based audit and the exclusive audit not being linked with other departments' works to the work process-focusing on audit with the participation of the executives and the audit supporting and adjusting the current firm's internal control system's problem diagnosis.

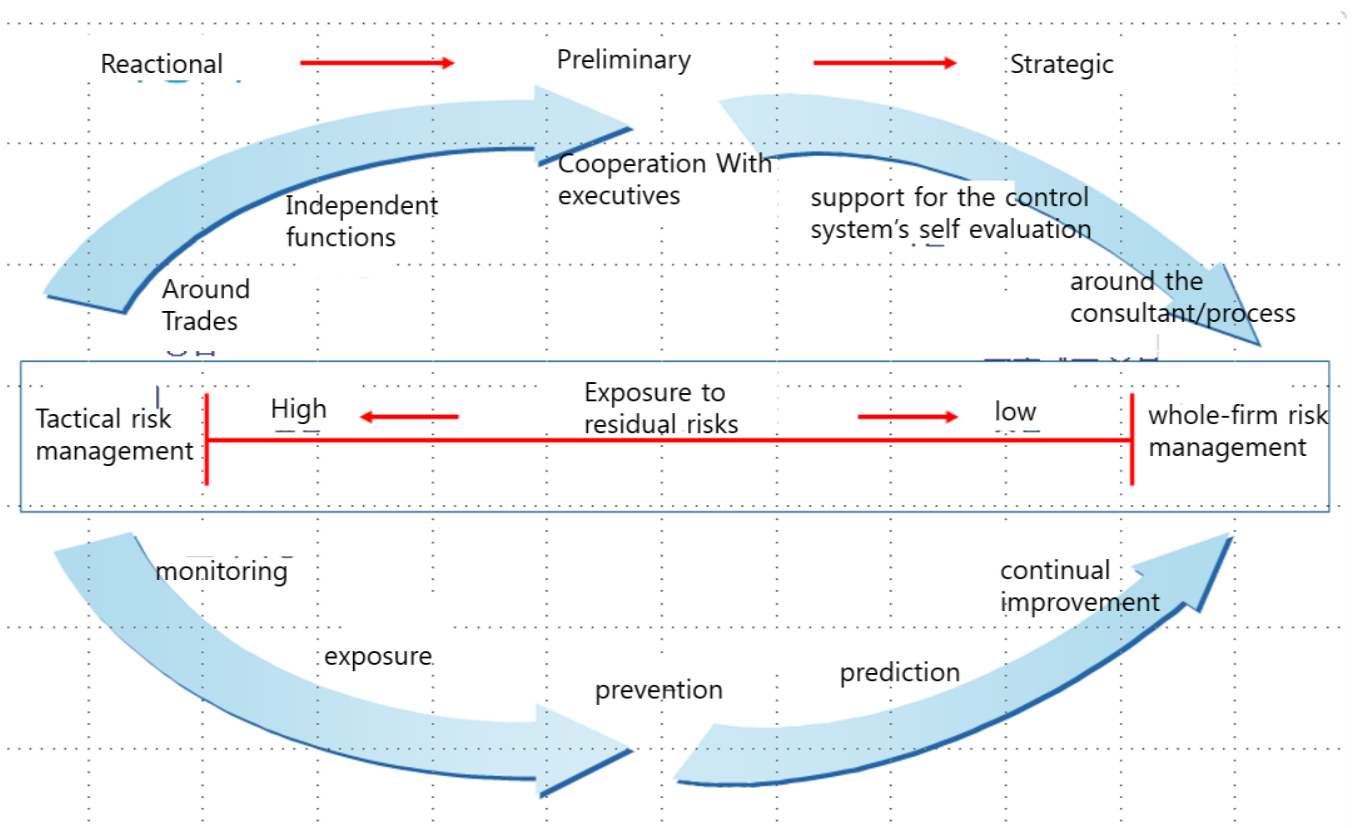

Figure 2. Direction of Internal Audit's Role Changes 
Besides, the management environment around firms is always floating so a firm's internal audit pursues for corresponding changes in order to keep up with the management environment's changes, so the firm's internal audit direction is changed toward the direction meeting the firm's executives' and interested parties' expectations. That is, beyond the past, industrialization-times audit mode around exposing a firm's misconducts, the current audit is being developed into the knowledge-based audit suitable for dealing the creativity in the knowledge-IT society where a process has a certain value and a firm's main asset is consisted of intangible knowledge information [Figure 2]. Also, it becomes a factor of necessary management tool for accomplishing a firm's all goals as well as improving the corresponding's internal organization operation's efficiency to establish the audit methodology and its tools as well as to construct an audit information system in order to contain the IT-biz environment in the audit's framework. Therefore the internal auditor is required to establish his/her role as a business partner, an internal consultant, not the role detecting and exposing faults in the firm any longer, and it is required to expand the audit scope around the work efficiency and effectiveness as well as to expand the prior audit's weight from the traditional posterior audit. Additionally, the techniques being required in the internal audit are, the need for the technique exposing and monitoring misconducts and accidents, the process analysis technique, the internal control/risk relevant knowledge, and the management consulting technique, and so forth as seen in the [Figure 3].

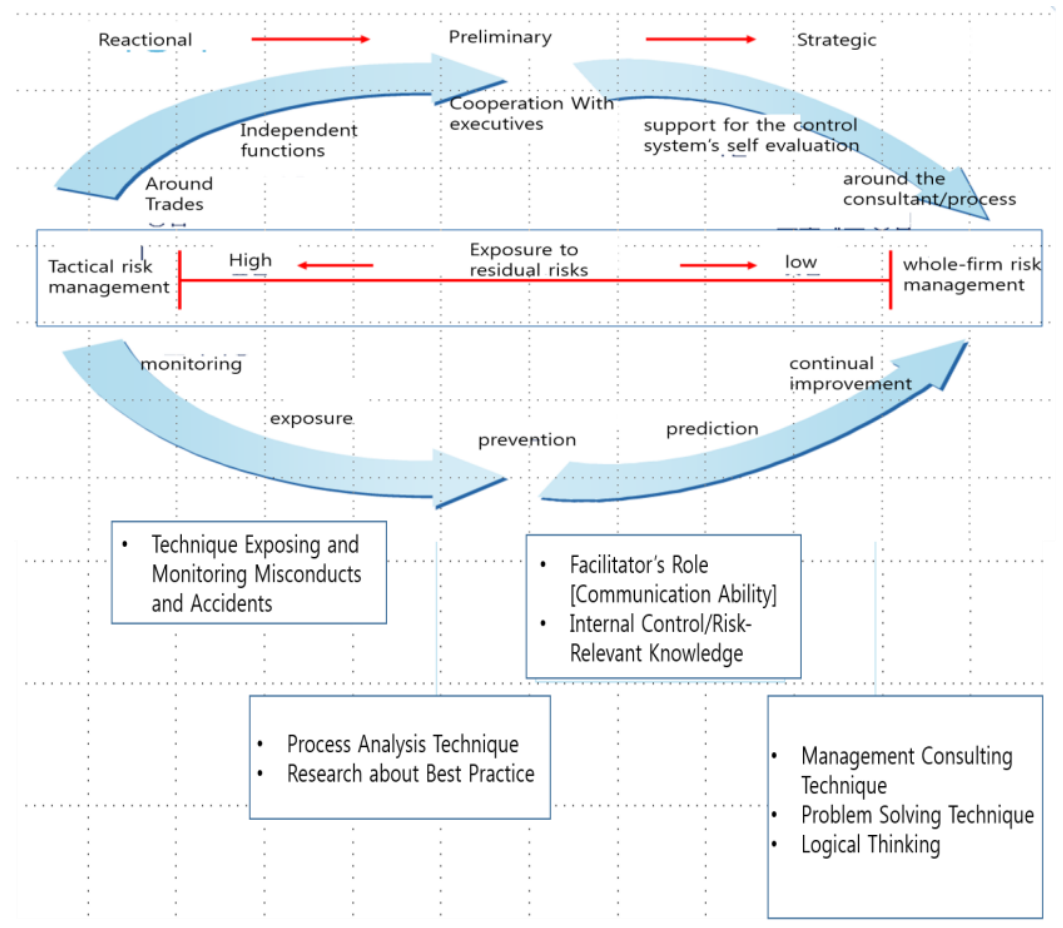

Figure 3. Technical Changes Requiring to the Internal Audit

\subsection{Internal Audit's Paradigm Change}

In order to predict the internal audit directions and trends in US, Asian and Pacific countries in the coming 5 years, the IIA (Institute of International Auditors) conducted a survey targeting main executives in each country. As the results from the IIA's survey predicting how the internal audit format would be changed in the future with supplement from the US Fortune's survey targeting the CAEs (Chief Audit Executives) of 250 firms and Asian main conglomerates and some additional surveys targeting some main experts and scholars, it was found that the internal audit-relevant major changes were as follows: 
The executives would want better internal audit services and there will be increased risk not to comply with the legal regulations because more new laws would be enacted And the existing internal audit's control perspective approach would not work any longer. In addition to that, the internal auditors would find their new values as an internal auditor, and the risk-based audit thinking would be more widely spread. (Source: International Audit 2012)

\section{Improved Audit Information System Model}

\subsection{Improvement Direction toward New Audit Information System}

In rapidly changing management environment, a public enterprises' internal audit work should be improved into the direction enabling the exercise of its strong control against the internal organization and to establish and keep core risk-management work in order that the enterprise can fully perform its value creation to maximize the firm's values and public services. Moreover, the international audit information system should improve the enterprise's risk-control system in order that the system can concentrate the audit resources on the priority risk factors, and should manage the audit cost that can be spent in proportion to the corresponding risk level, and the should keep its work flow's consistency through the high-technology's active utilization and the efforts of benchmarking other firms. The international audit information system also needs to secure the necessity for a new model of internal audit information system and the justification of such new model through the discovery of various cases to contribute in creating the enterprise's value through the enhancement of enterprise's project-execution ability at the same time. Also, the internal audit information system should establish a new internal audit plan focusing on the value, the evaluation and the responsibility and apply the plan to the internal audit. Additionally, the internal audit information system should establish a methodology of audit work's execution in order to minimize trials and errors, and should share/utilize the audit work's knowledge and information. Finally, the internal audit information system should be improved in order that it can accomplish the " information's appropriateness" through its IT audit, the " protection and economic utilization of IT resources, the 'accomplishment of IT process' efficiency and effectiveness".

\subsection{Improved Audit Information System Model}

As seen in [Table 4], the improved audit information system model aimed to improve the audit's efficiency, transparency and proper timing contrary to the existing eye-check method by constructing a computerization system utilizing the high-tech IT technology in the audit's all stages of audit plan, audit execution and audit report, and could delegate the priority audit targets into the 3 steps (low, medium, high risk classes) or 5 steps(1 5 steps) depending on the risk rank of department to be audited by introducing the risk scoring system. The suggested new model can quickly react and take corrective measures by automatically sensing and noticing any abnormal trades and problematic works being frequently exposed (Risk Pool) through its year-round monitoring. The new model enabled to share a firm's internal audit-relevant knowhow being accumulated by the auditors' experiences with other employees in the firm by reflecting the knowledge-based audit, a recent audit paradigm. Besides, the new model enabled to perform the audit works like any unusual audit beyond the existing audit areas, or some intensive analysis, and the audit about some fields where the manual audit had not been possible by introducing the firm's whole audit through the large-scale data process and utilizing some audit S/Ws (CAATs: Computer Assisted Audit Techniques). 
Table 4. Improved Audit Information System Model

\begin{tabular}{|c|c|c|c|c|}
\hline \multicolumn{3}{|c|}{ - Management of Audit Process } & \multirow[b]{2}{*}{$\Rightarrow$} & \\
\hline Audit Plan & \multirow[t]{2}{*}{$\Rightarrow$} & Audit Execution & & \begin{tabular}{l}
\multicolumn{2}{|c}{ Audit Results Report } \\
(Analysis \& \\
Management)
\end{tabular} \\
\hline $\begin{array}{l}\text { setting the audit plan. } \\
\text { (arbitrary appointment, based } \\
\text { on the work marks, etc) } \\
\text { (enter the priorities to audit) } \\
\text { arrangement of auditor and } \\
\text { audit schedule. } \\
\text { preliminary research and basic } \\
\text { data analysis. } \\
\text { management of external audit }\end{array}$ & & $\begin{array}{l}\text { (regular and special audits) } \\
\text { on-spot audit execution at } \\
\text { (field). } \\
\text { evaluate the checklist and } \\
\text { enter the audit results. } \\
\text { enter the auditor's opinion } \\
\text { and daily audit log (daily audit) } \\
\text { enter the acceptance of civil } \\
\text { complaints/accident handling } \\
\text { and the investigation results }\end{array}$ & & $\begin{array}{l}\text { make the audit report. } \\
\text { registration and } \\
\text { management of audit disposal } \\
\text { audit post-management } \\
\text { audit analysis and } \\
\text { management of audit } \\
\text { performance } \\
\text { (by auditor, by audit } \\
\text { institute, } \\
\text { by audit type, management } \\
\text { of performance against plan, } \\
\text { etc) management of audit quality } \\
\text { mate }\end{array}$ \\
\hline 仓 & & 仓े & & $\sqrt{3}$ \\
\hline \multicolumn{5}{|l|}{ Feedback } \\
\hline \multicolumn{3}{|c|}{ - Risk Management found in the Audit } & \multirow{4}{*}{$\Rightarrow$} & \\
\hline $\begin{array}{l}\text { Decision, Registration and } \\
\text { Management of Risk Evaluation } \\
\text { Items }\end{array}$ & \multirow[t]{2}{*}{$\Rightarrow$} & Early Warning(EW) & & $\begin{array}{l}\text { year-round monitoring and } \\
\text { Reactions } \\
\text { (Preliminary, Preventative } \\
\text { Management) }\end{array}$ \\
\hline $\begin{array}{l}\text { registration and } \\
\text { management of abnormal trades } \\
\text { (unusual trade conditions \& } \\
\text { alarm setting) } \\
\text { registration } \\
\text { management of risk pool and } \\
\text { (index, threshold condition } \\
\text { and alarm setting) } \\
\text { management of risk areas } \\
\text { and their changes }\end{array}$ & & $\begin{array}{l}\text { early warning like the } \\
\text { alarm function } \\
\text { alarm and reactions check } \\
\text { analysis of the same } \\
\text { warning }\end{array}$ & & $\begin{array}{l}\text { decision, registration and } \\
\text { management of the audit } \\
\text { department's items to monitor } \\
\text { request for anticipative, } \\
\text { prior actions } \\
\text { registration and check of } \\
\text { corrective measures } \\
\text { data analysis }\end{array}$ \\
\hline 仓ิ & & $\hat{\imath}$ & & $\sqrt{3}$ \\
\hline \multicolumn{5}{|l|}{ Feedback } \\
\hline \multicolumn{5}{|c|}{$\begin{array}{l}\text { - Knowledge Management for Regular Provision of Audit Information (Audit } \\
\text { atabase) } \\
\text { - Establishment of system to share various problems being pointed from the audit } \\
\text { nd the audit data }\end{array}$} \\
\hline
\end{tabular}

\section{Conclusions}

This study recognized and analyzed the status quo of public enterprises' internal audit system, their internal controls and the changes in the internal audit's paradigm as well as the recent audit trends. Through the research, this study could identify that the recent internal audit is evolved into a new model to contribute in enhancing a firm's competence by proposing an improved process that can meet the expectations of stockholders, interested parties and supervising authorities to a firm's operation appropriateness through its internal control function or compliance function, and can also enhance the firm's values. Besides, this study proposed an improved audit information system resulting from the recent trend that the recent audit is evolved into the risk-based and knowledge management-based audit. The fields in the proposed model by this study are not completely new fields but the fields which are somewhat recognized and included in the risk work process. However, it is expected that this new model can be utilized in reestablishing the functions of audit systems which are currently operated in each institute and enhancing the risk-based audit information system's complete construction level, and 내establishing the foundations for the high-quality internal audit which enables the audit 
process's innovation enabling internal, external customers' satisfaction and facilitates the organize to achieve its management goals.

\section{References}

[1] Y. H. Lee, "A Study on Development Direction based on Public Internal Audit Paradigm Shift", The Korean Journal of Audit and Inspection, vol. 7, (2002), pp. 69-95.

[2] M. S. Heo, H. J. Park, "A Comparative Study based on Public Audit System”, Korean journal of policy analysis and evaluation, vol. 19, no. 4, (2009), pp. 357-280.

[3] Y. S. Lee, "General Contemplation on the Internal Control System and American Cases", Postal Information Review, vol. 2005, no. 2, (2005), pp. 91-109.

[4] J. W. Lee, "Study on establishing and operating based on Control self-assessment System of Internal Auditing", The Korean Journal of Audit And Inspection Research Institute, vol. 9 no. 27, (2006), pp. 4650.

[5] H. R. Kim, "Audit Paradigm and Analysis Assessment of the Knowledge-based Information Society", The Korean Journal of Internal Auditor, no. 68, (2000), pp. 26-29.

[6] K. G. Seo, "Study on the development plan of the self-inspection of Local Educational Authorities", Graduate School of Educational Policy and Administration of Korea National University of Education in partial fulfillment of the requirements for the degree of Master of Education(Education Policy)in, (2015) February 2.

[7] H. Uidong,"A Study on the Operation Enhancement and Development Plan of Internal Audit Organization", Dept. of Public Administration Graduate School of Information and Industry Hanseo University, (2014).

[8] S. Ho, "A Study on Capability Improvement for the Internal Audit of Public Sector", Dept. of Public Administration Graduate School of Hanyang University, (2013) 08.

[9] S. Byungseok, "A Study on the Analysis of Internal-audit's Capability level and Improvement in Public Sector", Dept. of Aviation Business Administration Graduate School of Korea Aerospace University, (2012).

[10] Y.-w. Byun, "Study on the Enhancement of Independence and Professionalism of the internal audit: Focused on the internal audit of the defense acquisition program sector", Dept. of Business Administration Graduate School of Business Administration Hansung University University, (2011).

[11] D. W. Yang, "A Study of Measures to Improve Effectiveness of Internal Audit In public Enterprise", Dept. of Management of Technology Graduate School of Entrepreneurial Management Hanbat National University, (2009).

[12] Y. Ahn, "Searching for a Desirable Audit Consulting Method in Internal Audit System in Korea", The Korean Journal of Audit and Inspection, vol. 15, (2010) pp. 107-150.

[13] C. Ryo, "The Branding Strategy for Enhancing Internal Auditing Capacity", The Korean Journal Of Audit and Inspection, vol. 15, (2010), pp. 151-190.

[14] W.-S. Yong, H.-G. Cho and H.-I. Kang, "A Development of A Risk-Based Audit System Model in the Public Service Sector”, The Korean Journal Of Audit And Inspection, (2007) pp. 137-174.

[15] Committe os Sponsoring Organization of the Treadway Commission, COSO Enterprise Risk Management · Integrated Framework, (2004).

[16] M. S. Dorfman, "Introduction to risk management and insurance", Prentice Hall, (2005).

[17] The Institute of Internal Auditors, "International Standards for the Professional Practice of Internal of Auditing."

[18] M. Sterck, "International Audit Trends in the Public Sector", Internal Auditor, (2006) August.

[19] D. Richard, "Convergence between Internal Auditing and External Auditing-The Way Forward", The Institute of Internal Auditors. Altamonte Springs, FL, (2005).

\section{Authors}

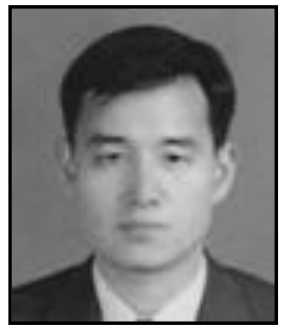

Jong-Suk Park, he received his master's degree of Public Administration in Sungkyunkwan University, Korea (2004). He worked in the IT field as a system engineer for over 20 years. Now $\mathrm{He}$ is CEO of S3I Co., LTD. since 2004. His current research interests include ITO, IT-governance, and IT audit. 


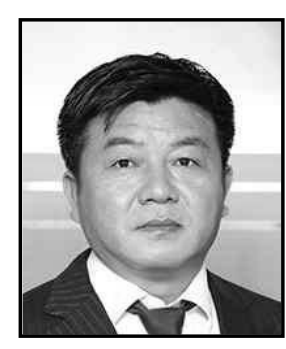

Young-Chul Oh, he received his bachelor`s degree in Business Administration from Korea Maratime and Ocean University in Korea, (1991). He got his master's degree in Computer Science at Soongsil University in Korea(2009), then he worked in the IT field as a System engineer for over 20 years. Now He is a CEO of S3I Co., LTD. since 2004.

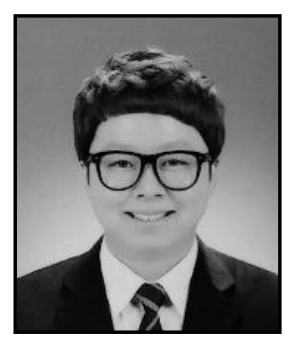

Jae-Gon Yoo, he received his bachelor's degree of Computer Science in Soongsil University in Seoul (2015). He is currently studying his master's degree of software engineering in Graduated Soongsil University, Seoul. His current research interests include Open Source Software and Software Engineering.

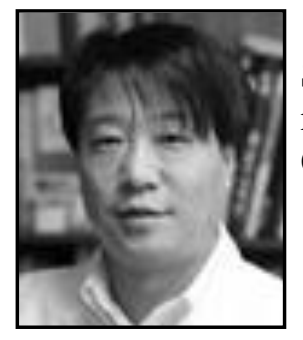

Yongtae Shin, he is a Ph.D. professor in the School of Computer Science and Engineering at Soongsil University in Seoul, Korea. His research interests focus on Multicast, IoT, Information Security, Content Security, Mobile Internet and Next Generation Internet.

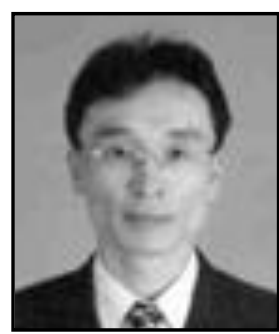

Jong-Bae Kim, he received his bachelor's degree of Business Administration in University of Seoul, Seoul(1995), his master's degree(2002) from the same university and doctor's degree of Computer Science in Soongsil University, Seoul(2006). Now he is a professor in the Graduate School of Software at Soongsil University in Seoul, Korea. His research interests focus on Software Engineering, and Open Source Software. 